\title{
A review of current research on group formation in early Christianity
}

\author{
J Eugene Botha \\ University of South Africa
}

\begin{abstract}
In this paper an attempt is made to gain a picture of the earliest stages of the Christian movement subsequent to Jesus' public ministry. Observations about methodological matters are made and this is followed by a brief discussion of a possible scenario regarding the earliest Christian groups. Some suggestions are also made with regard to the utilization of other disciplines such as social science methodology (with special reference to small group theories and sociolinguistics) which could be extremely helpful in obtaining a clearer picture of the earliest stages of the Christian movement
\end{abstract}

\section{INTRODUCTION}

This paper is an attempt to approach the earliest stages of the Christian movement from a fresh angle. The world of Jesus, what he did and taught, is a well-known field of study. Similarly, the church, as it emerged and developed later in the first and early in the second centuries, subsequent to the production of the Gospels, is also a theme not ignored by scholars. However, the interim, the time between the death of Jesus and the production of the Gospels, is a rather neglected field of study. What happened immediately after Jesus' earthly life? How did the church develop in its early stages? Was it a unified movement or perhaps a haphazard and diverse potpourri of groups? Was the dominant characteristic unity or diversity?

Many things commonly believed about these early stages of the Christian movement are not based on fact, but are the result of often untested assumptions based on an idealized perception about what the 'Church' should be. There are, of course, also a number of other reasons why we view the early church as we do. One reason is that we base our assumptions on a picture gleaned from documents dating from a time significantly later than the earliest stages of the Christian movement such as the completed Gospels, the book of Acts, the letters of Paul and documents of the Church Fathers. The central role of the Pauline corpus as a formative influence in perceptions about early Christianity is well recognized, but perhaps this should also be re-evaluated and brought into perspective. Mack (1988:5) argues that in the Pauline correspondence 
'there are no reminiscences of Jesus' activity, but only fragments from a Christ cult that had formed around the myths and rites in memory of his death and resurrection. The first surviving document to contain reminiscences of Jesus and his activity in Galilee comes from the early seventies'. Thus many of the documents produced by Christianity are later documents, and in addition to this the Gospels themselves are forms of propaganda and should not be mistaken for history - or even fact. These documents, including those the later church chose to uphold as 'canon', must be seen for what they are: documents designed to persuade groups of people and to refute opponents. So the historical content and factuality of these documents must be approached most circumspectly. Furthermore, what we believe and assume about the early church is often based on a depiction of Jesus and his followers which is not the result of what actually happened at the beginning, but perceptions about what ideally should have been or could have been, superimposed on the tradition so as to reflect exactly the same situation in Jesus' time as that of the document, and this would to a large extend legitimize the community who produced the document. Because of this, it is necessary to reflect anew on the earliest stages of the Christian movements, since chances are that the generally accepted picture might not be so accurate, and may to a large extent be totally fictional!

So the logical question to ask now is: 'What are the common perceptions regarding the early stages of the Christian movement?' and the answer is really quite simple. It is commonly believed that after the death, resurrection and ascension of Jesus the inner circle of his followers were united in their understanding of the nature of Jesus's mission and that shortly afterwards they expanded their movement, based on their understanding of Jesus' passion and teachings, firstly in Jerusalem, and then on to Samaria and other parts in the vicinity. This group in Jerusalem believed basically as we do today, and were indeed budding Trinitarians. The movement quickly gained momentum and large numbers of people flocked to the group and were baptized. This led to conflict with the Jews, and the Christians quickly established their own identity vis a vis the Jews, who started to persecute them. The movement spread and was soon established in Antioch and through missionary work by people such as Paul, sanctioned by the Jerusalem group, this unified message spread throughout the Roman Empire. As the message spread, churches were founded all over, and these churches were basically in agreement on all major aspects regarding the Gospel. A few early disputes such as the dispute between Peter and Paul were quickly resolved, and Christianity grew rapidly and apart from the Jews. Towards the end of this period, the Gospels came into being and, barring minor differences, they all reflect a neatly structured and homogeneous Christian movement. The Gospels came into being in different geographical settings 
and this explains many of the differences between them. It is also commonly held that major doctrinal differences emerged only many decades or even centuries after this. The scenario sketched hore is probably the accepted and most widely held picture of early Christianity and also serves as an ideal for many Christians to strive for: a unified Church of Jesus Christ, showing the unity and love and brotherhood of old.

Ideal as this picture is, there are many serious challenges that can be brought against it. Early Christianity did not develop in this way and was never ever a unified movement! This paper is an attempt at redefining these commonly held perceptions. It is necessary because many things Christians believe about matters such as ecumenicity and the church are based on perceptions regarding the early stages of the Christian movement, and a clearer picture pertaining to this, although disappointing to some, may help us to redefine the nature of institutions like the church a little better. The fact that we can today claim to know more than ever before about the first century Mediterranean world and the dynamics of that society necessitates this kind of study and a reevaluation of our commonly held perceptions.

In the course of this paper I shall attempt to define some areas of research that can shed light on how to approach these early stages and I shall also indicate some areas of research which can be of extreme importance in pushing the boundaries further in our quest to regain a clearer picture of the earliest Christianity. These aspects are not dealt with in any detail but are suggestions for further research.

\section{METHODOLOGICAL CONSIDERATIONS}

How should one go about an analysis of something like the early developmental stages of a social movement like the early church? What tools are at our disposal, what new data do we now have, how can we get beyond the common beliefs and the propaganda of the New Testament documents? This is of course no simple undertaking, and I shall attempt to show in a simplified manner how a possible programme could proceed. What I offer here is of course far from a complete programme but merely highlights of the four most important aspects which need to be considered in dealing with the development of the early Church. In the process I shall also point out a few areas of research which so far have not been explored. The four crucial aspects in an analysis of the developmental stages of the earliest Christian groups are:

* We have a number of literary artifacts dating from the era of the early church. We have grown accustomed to calling them Gospels and they are indeed the literary legacies of early communities and to some extent reflect what led to their creation. 
If Christian groups developed early on, the question is: 'Did they leave any recognizable traces behind in these literary artifacts? And if so, how do we get hold of these very early traces?'

* Closely aligned to the above is, of course, the question regarding the way in which we can proceed to gather some information from the existing material at our disposal. Here we need some input from methods developed to get at the dynamics behind the production of a particular document. If we know something about the literary history of the text, can we not also deduce some information about a possible community or group or school behind a completed document? And if this is the case, can we not perhaps also discern some kind of earlier groups in the documents?

* Another question that needs to be raised here is that relating to the actual sources at our disposal. Do the canonical documents give the only authoritative interpretation of the ancient world, or are there any other sources at our disposal?

* Another aspect of importance here is to ask the question regarding the development of groups. Do we know anything about how groups developed in the ancient world and what they looked like? If any such information exists it could be of extreme importance to our preset undertaking.

A number of fields of study in New Testament Studies/Second Testament Studies (developed and appropriated mainly in the course of the 20th Century) have yielded important data which we can utilize in this quest and which can help us in finding possible clues to the nature of the early Christian movement. We believe that during the course of especially, the latter part of this century various developments in the field of New Testament Studies have now made it possible for us to re-evaluate existing ideas about the earliest stages of the Christian movement, and to arrive at a totally new picture of what this development was like. These developments, which are crucial to our undertaking and which we should use in combination, are the following:

* During the middle decades of this century a renewed interest in the way in which biblical texts came into being marked the development of Source Criticism, Form Criticism, Redaction Criticism and Tradition Criticism. Here the focus was on how texts evolved and developed through a process from early collections of material, oral traditions and smaller units. It was found that the Gospels, for 
instance, were not documents produced as single literary works but were rather created as a result of a complex process in which various sections were molded together to form more or less unified wholes. The 'seams' of these documents and the processes of development were identified and carefully documented. In the last two decades studies on oral traditions and orality in the first century supplemented this research and focussed on the oral stages pre-dating the written Gospels. In addition to this work, research on the synoptic problem and the various solutions offered to this phenomenon (the fact that the synoptic Gospels show remarkable similarities and differences) also started to focus on the various strata present in the material, shorter collections of sayings of Jesus, passion narratives and the like, which were used to 'build' the Gospels. From this a complex theory was developed and $Q$ (a hypothetical source of material about Jesus, a source or 'Quelle') was postulated. $\mathrm{Q}$ studies abound and various layers and stages in the development of this hypothetical document have even been identified. Suffice to say, we now believe that the Gospels we have and even other documents outside our canon were not produced in a single unified manner and various stages of the pre-history of the texts can, in fact, be identified. This is important for our study of the early stages of the development of the Christian movement because this work done on the development of Christian texts and the oral tradition preceding it can indeed shed light on the early stages of the movement itself.

* The sources traditionally studied for information on the New Testament were the canonical scriptures and some authoritative Church Fathers. Many New. Testament scholars have in the past decades, subsequent to the discovery and publication of a large number of documents such as those at Nag Hammadi in Egypt, begun to reevaluate the worth of other extra-Biblical texts and to ask the question whether the term canon and the exclusive use of 'canonical' texts is indeed the correct way to proceed. To evaluate Biblical texts in terms of 'canon' is anachronistic because the canon did not exist at the time of the finalization of the various documents, and I believe that other documents apart from those in the 'New Testament' can indeed be priceless in terms of utilizing them to obtain a better understanding of the world of the earliest Christians. In this regard the Gospel of Thomas, a very early collection of Jesus words, now believed by some scholars to actually contain authentic 'Jesus words', that is, words actually uttered by the historical Jesus, is of significance, and other extra-Biblical sources such as the letter of Clement, the Didache, et cetera, are also increasingly utilized. In any case, it has become necessary to take other sources apart from the Bible into consideration when dealing with the early Christian movement. Strijdom (1995:127-128) also makes this point in his evaluation of the work done on the early Church. 
* Another new development in recent times is the appropriation of various methodologies of disciplines traditionally outside the scope of New Testament Studies by New Testament scholars. This has resulted in a veritable explosion of methodologies now available to us to examine the New Testament and the New Testament world. Methodologies from linguistics, literary criticism, reception theory, structuralism, deconstruction, ideological criticism, aesthetics, speech act theory, rhetorical criticism, social sciences and so on, abound in New Testament scholarship and are used in many exciting new studies. Some of these new fields of study are especially relevant for our present undertaking. Of special significance is the utilization of social science methodologies which shed light on social values, social institutions, and the social system of the ancient Mediterranean world in general. Certain aspects, such as groups and various models pertaining to group formation are especially significant in describing a possible scenario for the stages of group formation such as those of the early Christian groups.

* In our quest to get closer to the world of the earliest Christians, a field of study related to social scientific study of the New Testament is that of sociolinguistics. Its usefulness derives from the fact that language is a kind of social interaction and people speak and write to have some kind of social effect, and studies in the field have indicated that it is possible to construct a social context form the way in which people use language. This is also true of the language of the ancient world. We now know about the way in which the ancients constructed their world and viewed their world and how their social concerns shaped the language. It is indeed possible, by the use of sociolinguistics to arrive at a better understanding of a group through their writings. This is of course of cardinal importance for our study and in this paper we will use the Gospel of John as an example to show how this could be achieved.

With the above in mind, we can turn to an examination of the early Christian movement subsequent to Jesus' death and try to form a possible scenario.

\section{IDENTIFYING VARIOUS GROUPS IN THE EARLY CHURCH}

To speak in this context of the early church is of course anachronistic, because I believe one can really only talk about the early church from around the 4th Century, when some of the larger groups of the Jewish sect called the 'Christians' gained imperial favor and became a state religion. However, it is indeed possible to identify some early groups in the Christian movement and in this regard we will rely on the work done by Mack (1988a; 1988b; 1993), Crossan (1983; 1991; 1994), and Strijdom 
(1995), and this we will follow with an attempt at.a sociological classification of the nature of these early groups.

In all these analyses it is taken as a given that the documents we have at our disposal are to some extent compilations of earlier documents, which for their part are products of earlier groups. All these authors contend that it is indeed possible to arrive at some picture of the earliest groups responsible for creating these earlier collections of material.

According to Mack (1988a) it is possible to identify two major movements: one in Palestine and Syria and another set of groups of Christ cults in Northern Syria, Asia Minor and Greece. Both these movements consisted of many diverse smaller groups, but both movements regarded Jesus as the founder of their movements, and they all celebrated some kind of community meal, and constructed various myths around their founder figure. According to Mack (1988a) the former movement did not view Jesus as divine and their myths were constructed around his teaching and deeds. The latter groups in Asia Minor, Northern Syria and Greece on the other hand did indeed view Jesus as a divine figure and their myths were built around an interpretation of Jesus death and resurrection. Very significant for us to understand at this point is that right from the inception of the Christian movements, a significant number of 'early Christians' did not view Jesus as divine and had no traditions about a resurrection. Crossan (1994) differs from Mack in that he argues that while there were indeed early Christians for whom Jesus' death and resurrection were of no interest, they regarded the Jesus they believed in as divine. This is an important distinction, but we have decided to follow Mack's proposals here, because Crossan does not yet have a fully developed methodology (see also Strijdom 1995:112, who also indicates that Crossan's proposals have not yet reached a final stage).

\subsection{Early groups in Palestine and Southern Syria}

* A group in Galilee: The $Q$ community

Mack (1988a:84-87) calls this group of followers of Jesus 'The Itinerants in Galilee' and relates them to $Q$. Research into the existence of a separate (but now lost) Gospel called Q, which predates our existing Gospels, has reached a very sophisticated stage, and scholars such as Mack (1993) are constructing hypotheses about the community or group responsible for creating $Q$. Mack (1993) postulates that this group existed in Galilee in the years 30-70 CE, and that three stages in the development of this group can be discerned, reflected in Q1, Q2, and Q3. The first stage (30-40) reflects a community following a founder teacher in an unconventional life style, and a community working out and ordering various aphorisms, chreia and logia of Jesus to define their identity as separate group. A 
second phase (50-60) followed when this group experienced opposition from rival Pharisaic groups and religious leaders. They had to defend themselves and had to condemn their opponents in the most serious way possible. For this they introduced an apocalyptic picture of the founder, based on their interpretation of the Hebrew scriptures. The third phase (60-70) according to Mack (1988b:635) is where 'Q3 reveals an even more advanced stage of myth making. Jesus's appearance is now cast as a cosmic battle between the Son of God who knows how to interpret the "word of God" and the forces of evil that appear in Satan's temptation.' Mack emphasizes that even at this stage this particular group did not show any interest at all in the death of Jesus. Strijdom (1995:117) indicates that while Crossan differs from Mack in some respects, Crossan's work is still in its initial stages with regard to $Q$ and the nature of the community represented by it.

* A group in Jerusalem

Mack (1988a:88) calls this group 'The Pillars in Jerusalem'. This group established themselves in Jerusalem and did not venerate Jesus as divine, but constructed their myths around Jesus based on their understanding that Jesus was an authoritative teacher of the law. They were a Hasidic sect, which did not differ markedly from the other Pharisaic movements already established and trying to reform Judaism from within. They used the traditions about Jesus to legitimate their various purity practices, circumcision and rituals such as common meals. This group probably vanished when the Romans marched on Jerusalem in the last years of the sixties CE. Thus this group seems to be quite different from the picture we get from Paul and Luke concerning the Jerusalem congregation/group. According to Mack (1988a:88) the tradition created about the 'Pillars in Jerusalem' was the creation of later writers (such as Paul and Luke) who for various reasons wanted to trace back the origin of their brand of Christianity to Jerusalem. Thus it seems likely that the early 'church' (if we can call it that) in Jerusalem did not regard Jesus as divine, but merely regarded him as a teacher of significance who brought with him the possibility of reforming Judaism. Crossan (1994) differs from Mack in that he postulates that the early Christians in Jerusalem did reflect on Jesus' death.

\section{* A 'Jesus family' group}

According to Mack (1988a:90-91) a group similar to the group in Jerusalem (Hasidic, legalistic focus on Jesus' teachings only) functioned in northern Transjordan. For them it was of special significance to find their reason for existence in a close relationship with blood family members of Jesus. They also celebrated meals and 
built their myths around Jesus based on their relationship with Jesus and genealogical matters which resulted in tracing back the origin of Jesus (and thus the legitimacy of their existence as group) to King David. Mack (1988a:90-91) argues that:

Jesus' importance in the eyes of others may have been taken by his family as a challenge and chance to reverse the proverbial wisdom about a prophet's lack of honor in his own town. For a presumably peasant family in an insignificant village in the hills of Galilee, a son grown famous would have been a very important event. The normal approach would have been to emphasize the family relationships and speculate about genealogical questions'.

Mack bases his construction on the genealogy in found in Matthew, the $\mathrm{Q}$ tradition opposing this kind of group, and the fact that a similar Jewish-Christina Nazarene group existed in Transjordan.

* A group focused on miracles

Mack (1988a:91-93; 216-222) identifies another separate group ('The Congregation of Israel') also in existence in northern Palestine, which at their meals reflected on the myths regarding miracles of Jesus. They created the myths in the light of various Moses and Elijah-Elisha traditions. They associated Jesus with these traditions and the miracle stories told about Jesus reflect a group* of egalitarian nature, probably consisting of people of a diverse background and nationality, who use the miracle stories to legitimize the fact that they accept, over against the Hasidic purity rules, people from all walks of life and of varying degrees of purity. The miracles show how people of all origins are accepted and can become part of the new congregation of Israel. In this way this group could define themselves and could also legitimize their unique practices and rules. Strijdom (1995:120-121) indicates that Crossan differs from Mack in linking the miracle stories to James in Jerusalem and also in saying that the miracle stories were constructed not by peasants as Mack argues but by learned exegetes. However, Crossan's work in this regard is also preliminary and will be developed in future.

* A group in conflict with synagogues in Hellenistic cities

The existence of the so-called 'pronouncement stories' in the Gospel of Mark can be traced back to another separate Christian group (a synagogue reformist group) according to Mack's (1988a:94-96, 192-199) analysis. This group seriously ques- 
tioned the Pharisaic groups' and synagogues' teaching about purity laws, fasting, table fellowship, tithes, the Sabbath and so on. This they did by extending various aphorisms of their founder Jesus which later developed into the 'disputes' which are to be found in Mark. This group existed mainly in the Hellenistic cities of Galilee and southern Syria and did not focus on myths about Jesus' death and resurrection at all. Mack (1988a:95) also indicates that scholars date this group to the fifties and sixties of the first century.

\subsection{Christ Cults and Groups in Northern Syria, Asia Minor and Greece}

According to Mack (1988a:11; 98-123) it would seem that reflections on the death of Jesus did not develop in the immediate vicinity where he was active. Mack argues that followers of the Jesus movement came into contact with various interpretations about the Maccabees in Hellenistic Jewish intellectual centres such as Antioch. These interpretations focused on the fact that the Maccabees gave their lives willingly for the purpose of preserving the law. This was based on the Greek concept of a 'noble death'. In the light of this, the earliest Christians (possibly a group aligned to a synagogue reformist group) began to reflect on the death of Jesus and started to build a myth of the martyr death or noble death around the death of Jesus. They thus adapted their ritual meals to included elements reflecting this concept of a noble death. Recent research into the pre-Pauline traditions in Romans and Corinthians is used by Mack to indicate this. For instance, there are remarkable similarities between 4 Maccabees and Romans 3:25-26. Thus they began to interpret Jesus' death in terms of the Hellenistic ideal of a noble death in order to achieve some noble aim (the establishment of an ethnically mixed group in Antioch). This they combined with views regarding some kind of reward system, post mortem eternal life in the case of the Maccabees, but resurrection in the case of Jesus. Thus, the stages in the development were, in the first place, the reinterpretation of Jesus in terms of the noble death of a martyr (reflected in Rom 3:25-26, see Mack 1988a:109), secondly the element of resurrection as a reward for a noble death, reflected in I Corinthians 15:3-5 (see Mack 1988a:103-104), and thirdly the element of resurrection also relevant for the community. This final stage is described by Mack (1993:220) as: 'a spirited cult formed on the model of the mystery religions, complete with entrance baptisms, rites of recognition (the holy kiss), ritualized meals (the lord's supper), the notion of the spiritual presence of the lord, and the creation of liturgical material such as acclamations, doxologies, confessions of faith, and Christ hymns. It was a new religious society celebrating freedom from cultural traditions and the personal experience of transcending social constraints by means of induction into a mythic world centered in a symbol of transcendence and transformation'. From this interpretation it would seem that the interpretations of the death of Jesus and views on the resurrection developed separately from the tradition about Jesus 
as a teacher in Palestine and environs and that writers such as Paul were closer to these traditions. This also rendered the traditions about the words and deeds of Jesus a bit obsolete and we find very little reference to Jesus' earthly life in for instance Pauline traditions. Both Crossan (1994) and Hurtado (1990) question this analysis of Mack's and postulate that it is it indeed possible that there was reflection Jesus' death and on resurrection in Palestine too (see also Strijdom 1995:124-126). However, the fact remains that the early stages of the Jesus movement consisted of groups who paid no or scant attention to the death of Jesus while others started reinterpreting the death of Jesus to fit their perceptions regarding the foundation of the movement. (This immediately relativises the long established view of Paul as the centre of early Christianity, and this aspect and its far-reaching implications will need further attention in research).

From the above it is clear that we do not have a unified early Christianity.' It would seem better to talk of various Christianities in the early stages and to reckon with diversity rather that unity. All these groups existed side by side, all based on the founder Jesus, but with radically different interpretations of what he did, what he stood for, and what his teaching entailed. After the oral and early inscriptural phases, larger literary units were compiled, which developed into what came to the Gospels, and so various different traditions and interpretations of the Jesus-events were combined. One would suspect that this would lead to a more unified 'church', but this was not the case. Even the completed Gospels were produced to serve a specific purpose for a specific community, which felt the need to establish itself and draw boundaries by means of its writings, and to defend its own uniqueness.

\section{GROUPS, GANGS, FACTIONS AND SECTS}

If we accept the above analysis of the early stages of the Christian movement, it is perhaps also necessary to test these findings in the light of other disciplines which have become of extreme importance in the field of New Testament Studies. If we can evaluate our results against the insights offered by, for example, sociological analyses, it should offer us some kind of indication whether or not our initial analyses are feasible in terms of what we know about small group formation and development. This will give us a better picture of the sociology of the early Christian movement and would indicate whether or not the above analysis is sociologically possible. There is little doubt that the Christian movement had small beginnings and that it continued to function for many years in the form of small groups. However, there are quite a number of different kinds of groups, and to understand the initial movement of Christianity and its social implications a little better, it is necessary to make a few observations regarding small groups. For this we have to turn to small group theory, a separate field of study in sociology. We are merely giving some indication of what this kind of endeavour would entail; and certainly the work of Mack would need to be carefully analyzed in 
this regard, to find out whether or not the groups he identified are indeed possible sociologically speaking. Mack (1988a) give indications of various stages of develo ment in the early history of groups, such as conflict and so on, but his analyses are so far very rudimentary and could well be supplemented with research from small groups formation theories. So far this has not been done, and what is presented here is merely an indication of what promise these theories have for an analysis of early Christian groups.

A group may be defined as 'a plurality of individuals who are in contact with one another, who take one another into account and who are aware of some significant commonality. An essential feature of a group is that its members have something in common and that they believe what they have in common makes a difference' (Olmstead \& Hare 1978:11). This is, of course, a very broad definition of small groups and virtually any kind of group would fit this description. However, it is possible to define certain kinds of religious groups with a little more precision.

Small groups usually emerge because an individual with some leadership potential becomes aware of a need for change. This vision is shared with others who share the same conviction and thus group together to implement meaningful change is a specific cultural context with the expectation of a successful outcome. This definition would also hold true for the first century Mediterranean world, especially since the culture of the Mediterranean world functioned along the lines of groups and group formations. The question now arises what kind of small group the Jesus movement was and what kind of groups succeeded it.

Boissevain (1974:170-171) argues that we can distinguish two kinds of groups: groups of a more permanent nature, which he calls a 'corporate group', and groups formed around a distinct but limited purpose, which are of a temporary nature. Such a group can be called a coalition. 'The duration of the coalition will obviously vary with the length of time it takes to realize that purpose. Some coalitions prove to be viable units and longevity results' (Boissevain 1974:171). When the members of a coalition begin to commit resources to the group in order to achieve the goal, the coalition can be called an alliance. Coalitions or alliances can differ in size, from a few friends to hundreds of people entering an alliance to achieve a certain goal.

Boissevain (1974:173) mentions a number of features of coalitions/alliances which are illuminating in this context. They are:

* a centrality of focus in the form of a single central ego (leader)

* a clearly defined goal apart from mutual affection or interest

* internal specialization apart from the possession of a leader

* clear recruitment principles 
* density and interactional content

* behavioural norms (a common identity)

* the presence of rival or competing units in the environment

From the above it is clear that the early Christian movements fit this description very well. They share many of these features, and it is possible to view them as coalitions or alliances. There are, however, quite a number of further distinctions within this broader definition.

\section{Cliques}

'A clique is a coalition whose members associate regularly with each other on the basis of affection and common interest, and possess a marked sense of common identity' (Boissevain 1974:174). This coalition is temporary and many members may belong to one or more cliques at the same time. Some cliques have leaders, but it is not necessarily the case. Cliques usually have core members and secondary members who meet not as frequently as the core members, and the most important aspect of a clique is the emotional support it provides to its members. If we take this information into consideration, it is clear that it would be rather difficult to fit any of the early Christian groups into this category. They were clearly more than cliques.

\section{Gangs}

Gangs are notoriously difficult to define, but it would seem that a gang is a leadercentered coalition. 'In short, a gang is a large clique with a single leader who is both the symbol and central focus of the coalition' (Boissevain 1974:181). A gang shares all the characteristics mentioned above, but its main focus is the fact that a leader figure dominates and is the common binding factor. Against this background it would be possible to describe the initial Jesus group as a gang. Similarly the group formed around John the Baptist may be classified as a gang. These specific coalitions ceased to exist in their specific forms once the leaders were removed. It would perhaps be possible to classify certain groups in the early church who came into existence under the influence of strong leaders as gangs. Certainly some of the groups founded by Paul were not churches, but rather gangs, who in time developed into other kinds of groups. In addition, the early stage of the Johannine group was probably also structured socially as a gang, which centred around the leadership figure of John. 


\section{Action sets}

An action set is a 'set of persons who have co-ordinated their actions to achieve a particular goal .... While not questioning that an element of leadership is eventually necessary for the successful co-ordination of activities to achieve a goal, we should not rule out the possibility of a more spontaneous merger of people who think alike and gradually discover what they do. There leadership emerges as or after they join forces' (Boissevain 1974:186). All action sets eventually have some kind of leader, but this leadership can also be a clique and not only a single person. This description would probably fit the groups we have discussed under the "early groups in Palestine and Southern Syria', which seems to have come about spontaneously following the demise of the Jesus gang, and where not only individuals but also cliques (like the blood relatives of Jesus group) formed a central leadership. Furthermore, it is not necessary for members to have shared social relationships before recruitment. This means that these action sets can consist of a diverse number of people from various prior groupings and this would also seem to fit the picture of early Christianity.

\section{Factions}

Factions are much like gangs and action sets, but the crucial distinguishing element here is that a faction is in an overt or covert hostile situation in respect of a competitor or rival, and that this rivalry is basic to the existence of a faction. "The conflict is thus political. The prizes for which they compete may also include access to the "truth" (a form of power) and hence be ideological, as in a religious group or church .... Finally, factions are conflicting units formed within a larger encapsulating social entity such as a village, association or even another coalition, which had previously been united' (Boissevain 1974:195). Factions can be managed in different ways, but the introduction of an ideology can have the effect of strengthening the hold over the followers, and this is achieved by giving the followers a 'collective symbol and a sense of purpose by using causes, such as defending democracy and motherhood, helping the poor ... (Boissevain 1974:195). The initial Jesus gang did not have such symbols, but later factions ascribed to the founder Jesus in order to strengthen their own particular practices and to legitimate their faction's identity over against their opponents. Factions also tend to stren then themselves by introducing forms of bureaucracy. Thus in a more stable kind of environment, and if the conflict situation persists, factions can become more structured and as Boissevain (1974:198) indicates, they can become 'permanent competing structural units which are not leader centered but group centered'. This seems to be true of the Christian movements following the initial group formation stages, and it is certainly true of the later stages. For instance, a later situation as 
reflected in the Pastoral Epistles clearly reflects an emerging bureaucracy within the early church. I would also argue that the social grouping called a 'faction' can possibly be termed a 'sect' in a religious context.

\section{Sects}

A sect is a faction where a real distance between the parent body and the faction begins to show. Dissociation from the parent body begins to show and the groups/ factions take on the characteristics of a sect. Sects lay claim to the sole possession of true doctrine. If a sect has emerged from a parent body, it does not reject the teaching of the parent body totally but has a 'set of different emphases, with some elements added and some omitted ... the authority a sect invokes may be the superior revelation of a charismatic leader, it may be the reinterpretation of sacred writings .... Whatever it is, the sect rejects the authorities of the orthodox faith' (Wilson 1961:27-28). From this it is clear that Christianity gradually developed from a gang to a faction/sect. The parent body from which the Christian sects dissociated themselves is, of course, first century Judaism, but as for instance the letters of Paul indicate (Romans) there was no move to disassociate themselves completely from the Jews, and up until the time of Constantine in the fourth century, they were viewed as a Jewish sect, and not as a new religion.

\section{A New Religion}

A new religion might have its origin as a sect, and usually only when a sect becomes institutionalized and can claim some permanence apart from the parent body, can it really be called a separate religious movement. In the case of Christianity this only became possible when Christianity became the official state religion under Constantine in the fourth century CE. At that stage it was also possible for Christianity to dissociate itself so completely from its Jewish origins that we can begin to talk about a separate new religion.

With the above classification in mind, it would be necessary to scrutinize the various theories pertaining to the earliest groups and to substantiate findings with the results gleaned from sociology. This is an avenue of research which should receive further attention and would help us better to evaluate the findings of for instance Mack vis a vis those of Crossan. In addition, work on the stages groups go through (for example: 'forming, storming, performing, norming, adjourning' or 'orientation, dissatisfaction, resolution, production, termination') are also aspects which will assist us in arriving at a better and more comprehensive picture of early Christian groups. As indicated, 
Mack's analyses of the various groups and the stages they develop through could be greatly enhanced by input from various social analyses of groups regarding these aspects. This research still needs to be undertaken.

\section{THE JOHANNINE GANG: POSSIBILITIES OF SOCIOLINGUISTICS}

This is topic we can but briefly refer to in this context, but it must be kept in mind that just as the various sources and smaller units present in our Gospels give us a picture of early group formation, so too the completed Gospels, compiled from these various sources, were also constructed by a community for a specific community to answer some specific needs. So the gospels as we have them are also the reflection of specific communities, and much work has been done in this area. For instance the work of Culpepper (1975) and Brown (1979) on the Johannine Community is based on an analysis of the whole Gospel. Similarly, researchers such as Senior (1988) and Rohrbaugh (1994), based their analyses of the social location of Mark's audience on observations regarding the whole Gospel. But in these studies we have already moved beyond the initial stages of the various forms of Christianity and into a stage where groups were beginning to combine into larger groupings, where we can speak of sects. All of this should, however, not seduce us into thinking that, after the initial fragmentation of the early stages, incipient Christianity moved closer to unity. Far from it. The only difference was that the groups were now larger, more clearly defined, but of unity, as we would have liked, there is hardly any trace.

In this regard, we will turn to a single example of how analysis of groups can be done utilizing sociolinguistics. The example is the article of Malina (1994) on the Gospel of John, and the way it is used to locate and characterize the Johannine circle. Of special significance is the fact that Malina utilizes sociolinguistics in his analysis in a very creative way to point out that the language in John is a kind of anti-language which would indicate some kind of antisocietal group. For instance, what we know about the Johannine faction is that 'John's group was quite different from other Christian association in the first century Mediterranean .... John writes for people actually living in an alternate society imbedded in a larger society, that of "this world" and of "Judeans"' (Malina 1994:178). According to Malina (1994:181) John's group can be called an anti-societal association or group which is a kind of alternate society. This kind of association is, however, not a permanent arrangement, but a transitionary stage after which 'persons from alternate societies must eventually face the need to return to stable society and an articulation of Christianity befitting such stable society. Perhaps the Johannine letter likewise intimates this movement, with the beginnings of the dissolution of John's antisocietal group' (Malina 1994:181). 
With the above kept in mind, it is perhaps also necessary to re-evaluate the various stages of both the earlier and the later Christian groups, utilizing the new tools of social science theories and sociolinguistics to arrive at a better understanding of how Christianity developed. It must be pointed out that in research done by date insights from sociolinguistics have not been applied to the question of the earliest forms of Christianity. The various complexes and sources identified, which are considered to be legacies of these early communities, should be subjected to sociolinguistic analysis and this would yield significant results, shedding additional light on what we can know about these early communities. This research has yet to be undertaken.

\section{CONCLUSION AND IMPLICATIONS}

What are the conclusions and implications of the above? Can an academic activity such as this have any significance for us apart from yielding mere interesting new facts?

One can, of course, conclude this kind of study with the shattering news that our idealistic picture of the early Christian movement is far from realistic. In fact, we can conclude that the earliest Christians in Palestine did not even consider Jesus to be God or that he was resurrected after his death. There was probably no church in Jerusalem existing in the way we have usually thought about it, and it was only under the influence of Greek mystery religions and Jewish reflections on the Maccabees that Jesus became a Saviour figure in the early church. This can, of course, be shattering to ordinary believers and the fact can be used in this way. However, it is also possible to make some existential sense out of the data presented to us here. Instead of dismissing the Jesus movements as spurious group and loose alliances without any meaning for us, we can also take up the challenge to re-evaluate the historical truths and the religious truths about Jesus in the light of this very early diversity. Absolute truth claims about the nature of the church and the nature of the Christian faith can no longer be held. Christian truth differed from gang to gang, from group to group, from society to society, from faction to faction. But if one considers this carefully in the light of the later history of Christianity, was the picture ever any different? Is it necessary to be able to form a unified picture Christ, or the early church? Is it not perhaps more responsible to reckon with diversity right from the beginning and to take up the challenge presented to us by this, and view it as an opportunity rather than a disgrace, and to rediscover the inherent vibrancy and vitality of the Gospel of Jesus and the many ways to find existential meaning in the retelling of the Jesus narratives, just as the earliest Christians did. Whatever the case may be, it is essential that the research on these earliest stages of the Christian movement continues. 


\section{Works consulted}

Boissevain, J 1974. Friends of friends: Networks, manipulators and coalitions.

Oxford: Blackwell.

Brown, R E 1979. The community of the beloved disciple. New York: Paulist Press.

Catchpole, D R 1993. The quest for $Q$. Edinburgh: T \& T Clark.

Crossan, J D 1983. In fragments: The aphorisms of Jesus. San Francisco: Harper \& Row.

1991. The historical Jesus: The life of a mediterranean Jewsish peasant. Edinburgh: T \& T Clark.

- 1994. The historical Jesus in earliest Christianity, in Carlson J \& Ludwig R A (ed) 1994, Jesus and faith: A conversation on the work of John Dominic Crossan. New York: Orbis.

- 1995. Who killed Jesus? Exposing the roots of anti-semitism in the Gospel story of the death of Jesus. San Francisco: Harper Collins.

Culpepper, R A 1975. The Johannine school. Missoula, MT: Scholars. (SBL Dissertation Series.)

Hurtado, L W 1990. The Gospel of Mark: Evolutionary or revolutionary document. JSNT 40, 15-32.

Lacoursiere, R B 1980. The life cycle of groups: Group development stage theory. New York: Human Sciences Press.

Mack, B L 1988a. A myth of innocence: Mark and Christian origins. Philadelphia: Fortress.

1988b. The kingdom that didn't come. A social history of the $Q$ tradents, in: SBL Seminar Papers 1988. Missoula: Scholars.

- 1993. The lost Gospel: The book of $Q$ and Christian origins. San Francisco: Harper Collins.

Malina, B J 1994. John's: The Maverick Christian group. The evidence of sociolinguistics. BTB 24, 167-182.

Olmstead, M S \& Hare, A P 1978. The small group. 2nd ed. New York: Random. Rohrbaugh, R L 1994. The social setting of the Marcan audience. BTB 23, 114-127.

Senior, D 1988. "With swords and clubs ..." The setting of Mark's community and his critique of abusive power. BTB 17, 10-20.

Strijdom, J 1995. Diversiteit van die begin af: 'n Vergelyking van Mack en Crossan se konstruksies van die vroegste Christendomme (ca 30-70 nC). HTS 51/1, 108-133.

Theissen, G 1991. The Gospels in context: Social and political history in the synoptic tradition, tr by L M Maloney. Minneapolis: Fortress.

Wilson, B 1961. Religious sects: A sociological study. London: World University Library. 